\title{
THE BRITISH AND DANISH MONARCHIES' AWARDS OF ROYAL WARRANTS IN RELATION TO EU STATE AID LAW AND THE FREE MOVEMENT OF GOODS
}

\begin{abstract}
Anders Mihle*
Summary: This paper examines the effect of royal warrants in the United Kingdom (UK) and Denmark on the internal market of the European Union (EU) in relation to applicable EU legislation and case law on state aid and the free movement of goods. Firstly, the paper examines the British and Danish monarchies' selection procedures for the companies awarded royal warrants. Secondly, it discusses the economic effect of royal warrants on competition on the internal market. Thirdly, EU provisions and case law on state aid are outlined and discussed in relation to the award of royal warrants, followed by a discussion of the concept of the state and 'emanation of the state' in EU and national law. In order to complement the legal definition of state, the political role and powers of the Danish and British monarchies are examined. Lastly, royal warrants are discussed in relation to the free movement of goods (Article $34 \mathrm{TFEU}$ ) and the effect of ethnocentric campaigns on the internal market. It will be demonstrated that monarchies fall within the concept of 'emanations of the state' and that they are therefore obliged to comply with EU provisions on state aid and free movement of goods. The examination of the economic effect of royal warrants points to the fact that royal warrants distort competition and affect trade on the internal market because they are likely to provide selected businesses with a disproportionate advantage over their competitors. The paper concludes that the Danish and British monarchies' awards of royal warrants contravene the provisions on state aid and free movement of goods under EU law. The paper additionally demonstrates that monarchies favour products of their own national origin, which constitutes a discriminatory measure.
\end{abstract}

\section{Introduction - a twist of royal esteem}

Looking on the shelves in grocery stores such as Waitrose, Tesco, Sainsbury or a local kiosk, one will find various products that have a royal warrant of appointment awarded by either the British or the Danish monarchy (among others). ${ }^{1}$ When twisting and turning the product and

LLM European Union Law, University of Westminster. The author is grateful for the support and inspiration of Reader in Law, Dr Adam Lazowski, University of Westminster. Further comments are welcomed at anders@mihle.dk. 
finding the small label, one may wonder what the predicate actually means and what can be derived from the award.

The monarchies of the UK and Denmark have maintained a long tradition of appointing certain companies that supply goods to the royal household as purveyor to the Royal Court. ${ }^{2}$ By obtaining the right to apply a predicate to their products, the supplying companies have the advantage of indicating that they have achieved the prestigious status of supplier to the Royal Court. One may wonder how European consumers react to this label and whether it has an effect on the competition between the companies awarded and the companies who have not obtained this status. The potential problem of royal warrants is that they are not only a jolly cultural tradition, but that selected companies (often companies of national origin) are invited into an exclusive club where esteem is conveyed through the acknowledged favour of an institution, which may represent the state. This raises the question of whether royal warrants have a particularly beneficial effect on the producers who are thus awarded, as such an effect may have a significant impact on competition on the internal market and may affect trade within the EU. The key question here is whether the British and Danish monarchies represent the states of the UK and Denmark respectively, and whether in legal terms they can be characterised as 'emanations of the state'. In order to answer these questions, this paper examines the British and Danish monarchies' usage of royal warrants, their separate procedure for selection for the award 'by appointment to the court', and the concept of 'emanation of the state' pursuant to the case law of the European Court of Justice (ECJ) and national courts. Further, this paper will also seek to examine the economic effect of royal warrants and whether it may affect trade and distort competition within the EU.

Ultimately, this will enable us to see whether royal warrants are in accordance with the EU's provisions on state aid and the free movement of goods. The purpose of comparing the British and Danish monarchies is to compare the role of royal warrants in two Member States, and to examine how the two monarchies have developed their practice alongside the loss of national sovereignty to the EU and increasingly restrictive EU provisions in areas that affect trade in the internal market. However, it should be emphasised that this paper does not seek to answer or politicise the question of the general role of monarchies in the UK or Denmark or the future roles of these institutions.

\footnotetext{
1 Within the EU, the following monarchies also award royal warrants of appointment: Belgium, Monaco, the Netherlands and Sweden.

2 The designation 'Purveyor to HM the King' came into use at the beginning of the 19th century, whereas the designation 'Purveyor to the Royal Danish Court' was granted for the first time in 1904. Since then practice has been to grant 'Purveyor to HM The King' - at present 'Purveyor to HM The Queen' - to firms or individuals in direct contact with the Royal House and 'Purveyor to The Royal Danish Court' to firms supplying the Royal Household.
} 


\section{The award of royal warrants of appointment}

This section seeks to examine the selection process in the award of royal warrants to individual companies. Royal warrants are advertised on companies' products through the display of a coat of arms. Underneath the coat of arms usually appears a phrase, eg 'Purveyor to the Royal Court', 'Supplier to the Royal Court' or 'By Appointment to the Royal Court'. The royal warrant enables the supplier to advertise that they are supplying the royal family, thus gaining royal and glamorous prestige. ${ }^{3}$

\subsection{The British Monarchy - how to obtain a royal warrant}

To become a purveyor to the British Royal Court, individuals or companies must have supplied goods or services to the households of Her Majesty the Queen, His Royal Highness the Duke of Edinburgh or His Royal Highness the Prince of Wales for a minimum of five years. ${ }^{4}$ Purveyors to Her Majesty the Queen are entitled to use the Royal Arms as an integrated part of the firm name. Each member of the royal family can only grant one warrant to an individual business. ${ }^{5}$ However, businesses may obtain warrants from more than one member of the royal family. ${ }^{6} \mathrm{~A}$ royal warrant is in general granted for a period of five years and is regulated in the Trade Marks Act 1994. According to the monarchy, holders of royal warrants today represent a large cross selection of British trade and industry (approximately 800 warrant holders). However, as the Monarchy itself describes on its website, there are only a small number of foreign names. ${ }^{7}$

\subsection{The Danish Monarchy - how to obtain a royal warrant}

To become a purveyor to the Danish Royal Court and obtain a royal warrant, the applicant must have traded with the Royal Household or the Royal House regularly. Therefore, isolated deliveries and services for the day-to-day running of the Royal Household, to members of the Royal House or for grand occasions do not entitle businesses to a royal warrant. ${ }^{8}$ Furthermore, it is essential that the company is well-established, financially sound, well-managed and reputable. ${ }^{9}$ The Lord Chamberlain's Offi-

\footnotetext{
3 'Royal warrants' (The British Monarchy, 2008/2009) < http:/ /www.royal.gov.uk/MonarchUK/Symbols/Royalwarrants.aspx> accessed 23 August 2013.

4 'Royal warrants' (n 3).

5 'Royal warrants' (n 3).

6 'Royal warrants' (n 3)

'Royal warrants' (n 3).

8 'Hofleverandører' (Kongehuset) <http://kongehuset.dk/Organisation-og-kontakt/Hofleverandorer> accessed 23 August 2013.

9 De Kongelige Hofleverandører <http://www.hoflev.dk/hoflev4.asp> accessed 26 August 2013.
} 
ce assesses whether the application meets the conditions, whereupon the Queen personally assesses and appoints the new purveyor. ${ }^{10}$ Royal warrants of the Danish monarchy are regulated in Markedsføringslovens $\S 1,{ }^{11}$ Varemærkelovens $\S 14^{12}$ and Straffelovens $\S 132 .{ }^{13}$ The monarchy stresses that purveyors are broadly represented. However, according to their own information, there are only 6 foreign suppliers compared with 100 national suppliers. ${ }^{14}$

\section{The economic effect of royal warrants}

Based on the assumption that monarchies are an 'emanation of the state', it is necessary to determine whether royal warrants fall within the scope of state aid. To do this, I will examine the economic effect on the businesses that have been awarded a royal warrant in relation to their competitors in order to determine whether it is an advantage, and to what extent it might affect trade on the internal market and distort competition (domestically and inter-state). Miek Van der Wee gives two reasons in particular to explain why it is important for EU institutions to control the area of state aid. ${ }^{15}$ Primarily, state aid can be extremely harmful economically as it can distort competition between companies within the EU. If a company has easier access to subsidies, eg advertising, then this company will have an advantage over other companies, as it will be able to gain a larger share of the market and will also have less incentive to improve the efficiency of its operations. ${ }^{16}$ Secondly, state aid control at the EU level is important to protect the internal market of the EU, as subsidies can easily distort competition. Historically, during the foundations of the internal market, Member States agreed not to create barriers to free trade and fair competition. Competition can be distorted not only by the abusive behaviour of private companies, but also by governmental interventions, eg subsidies. This is why the European Commission (Commission), and not individual Member States, has the task of setting up effective safeguards to prevent individual Member States from giving domestic companies unjustifiable advantages over competitors from other Member States. ${ }^{17}$

\footnotetext{
10 Hofleverandører (n 8).

11 Bekendtgørelse af lov om markedsføring (Markedsføringsloven) LBK nr 58 af 20/01/2012.

12 Bekendtgørelse af varemærkeloven (Varemærkeloven) LBK nr 109 af 24/01/2012 .

13 Bekendtgørelse af straffeloven (Straffeloven) LBK nr 1028 af 22/08/2013.

14 Hofleverandører (n 8).

15 Miek Van der Wee, 'State Aid and Distortion of Competition' (Speech at the Conference on Competition Enforcement Challenges \& Consumer Welfare, Islamabad 2005) < http:// ec.europa.eu/competition/speeches/text/sp2011_17_en.pdf> accessed 2 August 2013.

16 Van der Wee (n 15).

17 'Royal warrants' (n 3).
} 
It is important to investigate the purpose and historical background of royal warrants and to examine the 'effect' they have on the companies that have been thus awarded. Royal warrants have been given to suppliers to the Royal Court for centuries and, as will be demonstrated later in this paper, they have a significant symbolic value for those who receive them. This leads us to the question of what a royal warrant indicates about the companies thus awarded. When products are given an advantage, for example by a quality label or by the endorsement of public figures or celebrities, it often has a positive effect on the products in terms of sales. Nonetheless, little attention or literature on the effect of royal warrants has come from the academic and media world. In a short documentary on the BBC, 'Are Royal Warrants the Ultimate Seal of Approval?'18 the effect of royal warrants was questioned. In the documentary, a British wine merchant in London, Berry Brothers \& Rudd, which has been a supplier to the Royal Court for many years, is asked how important it is to have this official seal of approval. The owner held that it was very important for the business and continued '... it makes us know that we are doing our job correctly'. The BBC further asks whether the owner thinks that customers are more likely to buy his products if they see the royal warrants. The business owner responds that he believes consumers see the royal warrants as a seal of approval which may indicate that if the product is good enough for the Queen (indicating the Queen's high expectation of quality) it is then good enough for the average consumer. Berry Brothers \& Rudd's statement indicates that their status as purveyor to the Royal Court has had a positive effect on their business, although this does not constitute statistically significant evidence. Danish journalist Jens Høvsgaard ${ }^{19}$ supports the claim that royal glamour has an effect on the selected businesses and in his recent book Det Koster et Kongerige he argues that many businesses do not offer gifts to the Danish Royal Family simply because they esteem the institution, but rather in the hope of the company and its products being 'sprinkled [with] royal glamour'20 and thereby increasing sales.

In relation to the recent celebration of the anniversary of the British Queen's Coronation, the Daily Express interviewed several royal warrant holders. ${ }^{21}$ Here, the holders clearly recount that the warrants

\footnotetext{
18 Tim Muffett 'Are Royal Warrants the Ultimate Seal of Approval?' (BBC News Business, 28 May 2012) <http://www.bbc.co.uk/news/business-18232594> accessed 28 May 2013.

19 Jens Høvsgaard is a Danish journalist who is a critic of the Danish Monarchy.

20 Jens Høvsgaard, Det koster et kongerige. Bag om kongehusets penge og privilegier (1. udgave, 2. oplag, Rosinante 2013) 163.

21 Melanie Whitehouse 'Fit for the Queen: The Companies Proud to be Royal Warrant Holders' Daily Express (London, 10 July 2013) <http://www.express.co.uk/news/ royal / 413717 / Fit-for-the-Queen-The-companies-proud-to-be-Royal-Warrant-holders> accessed 26 August 2013.
} 
have significant value. For instance, a textile manufacturer emphasises that the royal warrant is a sign of value. ${ }^{22}$ A chocolatier states that the royal warrant is a great badge of esteem and highlights that being a royal warrant holder means being part of an extraordinary club. ${ }^{23}$ Additionally, one of the latest companies to receive a royal warrant, Covent Garden Flower Market, was asked by the BBC about the kind of impact the new title of Purveyor to the Royal Court has had on the business. ${ }^{24}$ The owner held that the impact had not been economically good. However, he stated that it had given prestige to the business and existing customers and customers around the market had applauded the award. Other business owners argue that a royal warrant signifies a standard of service, quality and liability. ${ }^{25}$ As the above-mentioned statements indicate, it may be argued that royal warrants do not necessarily always give an economic advantage to companies. Besides, it may not always serve as a good advertisement for companies who sell their products in countries where the British monarchy is generally disliked because of the country's political orientation or historical events. Vicky Bullen from Coley Porter Bell Brand Design draws attention to the fact that royal warrants have a positive effect in the UK and Asia, where they are still a mark of prestige, and also in the United States. ${ }^{26}$ Nonetheless, she also states that they may not necessarily be an advantage in countries that do not like monarchies and/or the UK. ${ }^{27}$ In another article from the BBC about a Northern Irish company which has recently been awarded a royal warrant, the business emphasised that '... to have that kind of independent recognition of what we do will serve us well moving forward'. ${ }^{28}$ Again, it is emphasised that a royal warrant provides a label of prestige, success and quality.

The above-mentioned interviews with companies that have been awarded royal warrants indicate that the warrants have had a positive effect on their businesses. Overall, it can be argued that royal warrants can be considered 'free' advertising and marketing subsidised by the government - if we assume that monarchies are an emanation of the state. The advertising here takes the form of quality labelling, which gives undue advantages to selected companies. Nevertheless, it is important to clearly state that the interviews do not constitute any proof or significant statistical data, and thus it is not possible to generalise the effect of royal warrants on the in- 
ternal market. In order to give a precise assessment of the effect, more data and examinations will be needed. As the task of statistically examining these effects requires substantial resources, a statistical survey does not form part of this paper. However, the 'examination' from the sources above still gives us a qualitative idea about how the effect of royal warrants may work. Thus, if royal warrants do give some businesses advantages over other businesses in terms of sales, they may be a serious threat to trade and may distort competition on the internal market of the EU.

\section{State aid under EU law}

In order to discuss the question of royal predicates, it is essential to outline the EU law on state aid and to whom it applies. The objective of state aid control is to ensure that government interventions do not distort competition and trade inside the EU, as laid down in the founding Treaties of the European Communities. ${ }^{29}$ In this respect, state aid is defined as an advantage of any form conferred on a selective basis to undertakings by national public authorities. ${ }^{30}$

\subsection{Legal basis}

Article 3(3) of the Treaty on European Union (TEU) verifies that: '... the Union shall establish an internal market. It shall work for the sustainable development of Europe based on balanced economic growth and price stability and a highly competitive social market economy...'

Regulations on state aid are provided in Article 107 of the Treaty on the Functioning of the European Union (TFEU), which defines that state aid and measures having equivalent effect are subject to general prohibition. Under Article 107(1) TFEU, the concept of state is not restricted to the federal or central authorities of Member States, but includes regional and local bodies, whatever their status. ${ }^{31}$ This indicates that state aid may emanate from any body within the public sector, pursuant to the Air France $v$ Commission case. ${ }^{32}$ Article 108(1) TFEU lays down that the Commission reviews existing aid policies and proposes any measures required by the progressive development or functioning of the internal market. Article 108(2) TFEU states that if the Commission finds aid granted by a state or through state resources to be incompatible with the internal market pursuant to Article 107 TFEU, or if it is being misused, it shall

\footnotetext{
29 Michelle Cini, 'The Soft Law Approach: Commission Rule-making in the EU's State Aid Regime' (2001) 8(2) JEPP 192, 196.

30 Europa/European Commission, Competition, 'State Aid Control Overview' <http:// ec.europa.eu/competition/state_aid/overview/> accessed 2 August 2013.

31 Kelyn Bacon, European Community Law of State Aid, (OUP, Oxford 2009) 26.

32 Case T-358/94 Air France $v$ Commission [1996] ECR II-2109, para 56.
} 
decide that the state concerned must abolish or alter such aid policies within a period to be determined by the Commission. Article 108(3) TFEU prescribes that prior to granting new or altering existing aid, states must inform the Commission, which will submit its comments. If the Commission finds that the aid is not compatible with the internal market it will undertake the procedure under Article 108(2) TFEU.

Article 107(1) TFEU applies to aid of any form pursuant to Steenkolenmijnen $v$ High Authority. ${ }^{33}$ In relation to the question of whether the granting of state aid can be seen as a breach of EU law, it follows from Article 107(1) TFEU that the measure would be liable to distort competition and affect trade between Member States. The test defines whether the aid strengthens the position of an undertaking in relation to its competitors pursuant to Siemens $v$ Commission ${ }^{34}$ and Ter Lembreek $v$ Commission, ${ }^{35}$ where it has been determined that it may be regarded as aid even if it extends to the whole sector. The following review of the provisions on state aid is a selection of the relevant criteria and case law for this paper's focus on royal warrants.

\subsubsection{State aid granted through state resources}

Article 107(1) TFEU applies to aid granted by a Member State or through state resources. In the Preussen Elektra case, ${ }^{36}$ the ECJ defined that a measure is not state aid unless it is financed through public resources. ${ }^{37}$ Advocate General (AG) Jacobs gave a 'narrow' and 'wide' view on the interpretation of Article 107(1) TFEU in Preussen Elektra, where he held that any measure which confers economic advantages on specific undertakings, and which is the result of conduct ascribed to the state, should be considered state aid. ${ }^{38}$ On the other hand, he argues that Article 107(1) TFEU may be interpreted in the sense that financing through state resources must be seen as a constitutive element of the definition of state aid. ${ }^{39}$

\subsubsection{State resources}

Funds and assets granted through central government institutions constitute state resources. ${ }^{40}$ The same also applies to regional or local authorities. ${ }^{41}$ The crux of the question is whether state resources are

\footnotetext{
33 Case 30/59 Gezamenlijke Steenkolenmijnen in Limburg v High Authority [1961] ECR I, para 19.

34 Case T-459/93 Siemens $v$ Commission [1995] ECR II-1675.

35 Case T-217/02 Ter Lembeek $v$ Commission [2006] ECR II-4483.

36 Case C-379/98 Preussen Elektra [2001] ECR I-2099.

37 Bacon (n 31) 69.

38 Preussen Elektra (n 36) Opinion of AG Jacobs, para 115.

39 ibid para 116.

40 Bacon (n 31) 69.

41 Cases T-228 and 233/99 Westdeutsche Landesbank $v$ Commission [2003] ECR II-435.
} 
involved in the measure. The state resources criterion is met in circumstances where the aid originates from a levy system. ${ }^{42}$ The ECJ emphasised in Steinike und Weinlig $v$ Commission ${ }^{43}$ that, when applying Article 107 TFEU, the focus should be on the effect of the aid and not on the status of the institutions entrusted with the distribution and administration of the aid. Nevertheless, where aid is granted through a public or private undertaking, it is necessary to show whether the funds in question are under state control. ${ }^{44}$ If it is determined that the funds derive from general taxation, they may be regarded as state resources when they are derived from parafiscal charges or other compulsory contributions, where the fund is under the control of the public authority. ${ }^{45}$ Nonetheless, in the Pearle case, ${ }^{46}$ the ECJ held that where parafiscal levies are earmarked for a specific purpose and are not under the control of the public authorities, the fund does not necessarily constitute state resources. ${ }^{47}$

\subsubsection{The imputability criterion}

Through its case law, the ECJ has established that a measure is only state aid if it is attributable or imputable to the state. ${ }^{48}$ Where an advantage is granted through the resources of a public or publicly owned undertaking, imputability to the state cannot be inferred, which applies to many cases. ${ }^{49}$ However, AG Jacobs opined in France $v$ Commission ${ }^{50}$ that the day-to-day business decisions of a publicly owned undertaking taken without any interference from the public authorities should not fall within the scope of state aid rules. In the latter case, the ECJ held that it was necessary to examine whether the public authorities were actually involved in the adoption of the measures. ${ }^{51}$ However, it follows from the ECJ that the formal independence of a public body from the state is not in itself sufficient to exclude it from state liability. ${ }^{52}$ The ECJ held in Air France $v$ Commission ${ }^{53}$ that the conduct of a public sector body was attributable to the state, even though it enjoyed legal autonomy from the political authorities of the state. The ECJ concluded that the creation of independent institutions that allocate aid could not circumvent rules on

42 Bacon (n 31) 73.

43 Case 78/76 Steinike und Weinlig v Commission [1977] ECR 595, para 21.

44 Bacon (n 31) 74.

45 ibid.

46 Case C-345/02 Pearle [2004] ECR I-7139, para 36.

47 Pearle (n 46).

48 Bacon (n 31) 77.

49 ibid.

50 Case C-482/99 France $v$ Commission [2002] ECR I-4397, Opinion of AG Jacobs, para 55.

51 France $v$ Commission (n 50), judgment, para 52.

52 Bacon (n 31) 78.

53 Case T-358/94 Air France v Commission [1996] ECR II-2109 122, para 62. 
state aid.${ }^{54}$ Where undertaking the measure does originate from the state, there is high probability that it may indicate imputability to the state even if a private undertaking carries out the measure. ${ }^{55}$ On the other hand, it can be argued that if the initiative to provide aid comes solely from the private undertaking, this does not necessarily constitute imputability to the state. ${ }^{56}$ In the Pearle case,${ }^{57}$ the ECJ held that when parafiscal levies are earmarked for a specific purpose and are not under the control of the state, it might not fall within the scope of state aid. ${ }^{58}$

\subsubsection{State aid favouring certain undertakings or the production of certain goods}

The advantage to certain undertakings may only be an incidental effect of a measure which in fact is a general measure that applies to all undertakings. ${ }^{59}$ It has been held in case law that a measure is in principle selective if it provides advantages exclusively to certain undertakings or certain sectors of activity. ${ }^{60}$ To examine whether this is the case, it is essential to define the point of reference in order to compare different undertakings. ${ }^{61}$ However, this is not always a simple task. In its case law, the ECJ has emphasised that a comparison of undertakings in terms of whether or not an advantage exists should be made in a 'comparable legal and factual situation', based on the premises that it is in breach of the EU's provisions on state aid. ${ }^{62}$ Provided that the aid measure favours specific undertakings, it does not matter if the aid is granted to a very large group of beneficiaries, which the ECJ has emphasised in its case law. ${ }^{63}$ Even if the aid is given to a large group of beneficiaries, it will still constitute state aid. ${ }^{64}$ There are various categories of selective aid, irrespective of whether this concerns direct or indirect aid to particular sectors, ${ }^{65}$ selection by size and resources, ${ }^{66}$ geographic regions within the Member

\footnotetext{
54 ibid paras 63-67.

55 Case C-126/91 GEMO [2003] ECR I-13769, para 26,

56 Bacon (n 31) 79.

57 Pearle (n 46).

58 Bacon (n 31) 74-79.

59 ibid 80.

60 ibid.

61 ibid 80-81.

62 Case C-143/99 Adria-Wien Pipeline [2001] ECR I-8365, para 41; Case C-409/00 Spain v Commission [2003] ECR I-1487, para 47; Case C-308/01 GIL Insurance [2004] ECR I-4777, para 68; Case C-172/03 Heiser [2005] ECR I-1627, para 40; Case C-88/03 Portugal v Commission [2006] ECR I-7115, paras 54 and 56.

63 Case C-75/97 Belgium v Commission [1999] ECR I-3671, para 32; Case C-143/99 AdriaWien Pipeline [2001] ECR I-8365, para 48.

64 Bacon (n 31) 82.

65 ibid 81 .

66 ibid 82.
} 
State, etc. ${ }^{67}$ Highly relevant for this paper, the ECJ held in Commission $v$ France $^{68}$ that a certain discount exclusively provided for national products that were exported was considered selective aid under EU law. ${ }^{69}$ The aforementioned examples are merely random, and the list of selective aid is not exhaustive. ${ }^{70}$ Nevertheless, aid that benefits all undertakings in the national territory, eg a uniform tax reduction within a Member State, is a general measure and is not considered state aid under EU law. ${ }^{71}$

\subsubsection{State aid distorting competition}

Under Article 107(1) TFEU, state aid should not distort competition. According to the case law ${ }^{72}$ of the ECJ, it is not necessary to demonstrate any actual effects on competition or trade for state aid provisions to apply, as the Commission will not be able to determine whether new aid has an effect on competition or trade, but only to assess whether it does so hypothetically. ${ }^{73}$ To determine whether aid distorts competition, it should be examined whether the aid strengthens the position of the business in relation to its competitors. ${ }^{74}$ However, it is not necessary to examine the competitors' position on the market, as it has been determined by the ECJ that a measure may be regarded as aid even if it extends to the whole sector. However, the question of strengthening the company's position should be assessed by defining whether the business's financial position as a whole is improved by the aid. ${ }^{75}$ The ECJ has emphasised through its case law $^{76}$ that aid which is intended to relieve a business of the expenses that it normally has to cover in its day-to-day budget or its usual activities principally distorts competition. ${ }^{77}$ Furthermore, the ECJ has held ${ }^{78}$ that if aid is granted in a sector characterised by intense competition it will usually distort, or at least risk distorting, competition.

\footnotetext{
67 ibid 83.

68 Cases 6 and 11/69 Commission v France [1969] ECR 523.

69 Bacon (n 31) 84.

70 ibid.

71 ibid 85.

72 Case C-374/97 Italy v Commission [2004] ECR I-3679, para 44; Cases T-304 and 316/04 Italy and Wam $v$ Commission [2005] ECR I-10901, para 64.

73 Case T-298/97 Mauro Alzetta $v$ Commission [2000] ECR II-2319, para 77.

74 Bacon (n 31) 94-96.

75 Cases 62 and 72/87 Exécutif Regional Wallon v Commission [1988] ECR 1573, Opinion of AG Linz para 20, and judgments paras 14-15; Case T-14/96 Bretagne Angleterre Irlande $v$ Commission [1999] ECR II-139, para 78.

76 Case T-459/93 Siemens $v$ Commission [1995] ECR II-1675, paras 48 and 77; Case T-214/95 Vlaamse Gewest $v$ Commission [1998] ECR II-717, para 43; Case T-217/02 Ter Lembeek $v$ Commission [2006] ECR II-4483], para 177.

77 Bacon (n 31) 96.

78 Case T-214/95 Vlaamse Gewest $v$ Commission [1998] ECR II-717, para 46; Case T-217/02 Ter Lembeek $v$ Commission [2006] ECR II-4483], para 178.
} 


\subsubsection{De minimis aid}

The ECJ has held in various cases ${ }^{79}$ that even small amounts of aid - de minimis aid - may distort competition and affect trade between Member States. ${ }^{80}$ Accordingly, it is not essential to determine whether the aid has a significant or substantial effect, ${ }^{81}$ and Article 107(1) TFEU does not set any specific amount or level for aid not to be considered to affect competition or trade between Member States. ${ }^{82}$ However, there is an exception to this rule (see 4.1.5).

\subsubsection{State aid affects trade between member states}

The requirement for it to be determined whether state aid affects trade between Member States is an important one as this indicates whether the aid falls within the scope of the legislative jurisdiction of EU law or national law. ${ }^{83}$ It is therefore important to examine whether certain aid strengthens the position of one business compared with others on the internal market of the EU. However, to fall within the scope of state aid, it is not necessary for businesses to operate at an inter-state level in the EU, ie in the markets of more than one Member State. ${ }^{84}$ In a situation where the business only operates at the local level, ie it does not export its products, it may still affect trade in the internal market, since the beneficial aid may strengthen the business's position in the local market, ${ }^{85}$ which may be a disadvantage for other businesses from other Member States and thereby a potential barrier for them to enter that market. ${ }^{86}$

\subsubsection{Derogations}

The Treaty pronounces the general prohibition of state aid. Nevertheless, the founders agreed that in some circumstances government interventions are necessary for a well-functioning and equitable economy, ${ }^{87}$ especially during periods of financial crisis. Therefore, the Treaty leaves room for a number of policy objectives with which state aid can be consi-

\footnotetext{
79 Case C57/86 Greece v Commission [1988] ECR 2855 paras 17-18; Case C-142/87 Belgium v Commission [1990] ECR I-959, para 43; Case C-310/99 Italy v Commission [2002] ECR I-2289, para 86; Case C-172 Heiser [2005] ECR I-1627, para 32.

80 Bacon (n 31) 100.

81 Case T-55/99 CETM v Commission [2000] ECR II-3207, para 94.

82 Case C-71/94 Administracion del Estado v Xunta de Galicia [2005] ECR I-7419 para 41.

83 Bacon (n 31) 97.

84 Case C-393/04 and C-41/05 Air Liquide Industries Belgium [2006] ECR I-5293, para 35.

85 Case 102/87 France $v$ Commission [1998] ECR 4067, para 19; Case C-303/88 Italy $v$ Commission [1991] ECR I-433, para 27; Case C-75/97 Belgium v Commission [1999] ECR I-3671, paras 47-49; Case T-298/97 etc Mauro Alzetta $v$ Commission [2000] ECR II-2319, para. 91; Case C-280/00 Altmark [2003] ECR I-7747, paras 77-78.

86 Bacon (n 31) 98.

87 Europa/European Commission (n 30).
} 
dered compatible. Article 107(2) TFEU determines three areas that might be compatible with the internal market. However, only Article 107(2a) TFEU is relevant for this paper and determines that aid having a social character for individual consumers may be compatible with EU law, provided that the aid does not discriminate in relation to the origin of the product concerned. Furthermore, Article 107(3) TFEU provides five exceptions that may be compatible with the internal market: (a) aid to promote regional aid; (b) projects of common European interest or seeking to counter serious disturbance in the economy of a Member State; (c) the development of certain economic activities or of certain economic areas; (d) cultural aid; and (e) aid specified by a decision of the European Council (Council). There are currently two Block Exemption Regulations. Firstly, the de minimis aid regulation ${ }^{88}$ exempts, among other things, aid below $€ 200,000$ over a period of three years under certain conditions. Secondly, the General Block Exemption Regulation (GBE) ${ }^{89}$ exempts from notification to the Commission various forms of aid $^{90}$ up to certain specified monetary ceilings. ${ }^{91}$ In addition to the general exemptions, there is also a range of sector specific regulations governing grants of aid, and the Council has recently introduced new categories ${ }^{92}$ that the Commission may exempt from the obligation to prior notification. ${ }^{93}$

\footnotetext{
88 Commission Regulation (EC) 1998/2006 on the application of Articles 87 and 88 of the Treaty to de minimis aid [2006] OJ L379.

89 Commission Regulation (EC) 800/2008 declaring certain categories of aid compatible with the common market in the application of Article 87 and 88 of the Treaty (General block exemption Regulation) [2008] OJ L214.

90 It follows from the GBE that the following are compatible with EU state aid law: SME investment and employment; small enterprises newly created by female entrepreneurs; consultancy in favour of SMEs; SME participation in fairs; provision of risk capital, research and development; technical feasibility studies; industrial property rights costs for SMEs; research and development in the agriculture and fisheries sectors; young innovative enterprises; innovation advisory services and innovation support services; the loan of highly qualified personnel training; recruitment of disadvantaged workers in the form of wage subsidies; employment of disabled workers in the form of wage subsidies; compensating the additional costs of employing disabled workers; regional investment and employment; newly created small enterprises in assisted regions; investment to go beyond Community standards for environmental protection; acquisition of transport vehicles which go beyond Community environmental protection standards; early adaptation to future environmental standards for SMEs; investment in energy saving measures; investment in high efficiency cogeneration; investment in the promotion of energy from renewable energy; environmental studies and the environment, in the form of tax reductions.

91 Including aid in favour of SMEs; aid for research and innovation; regional development aid; training aid; employment aid; aid in the form of risk capital; environmental aid and aid promoting entrepreneurial activity.

92 New categories include aid for innovation, culture, natural disasters, sport, certain broadband infrastructure, other infrastructure, social aid for transport to remote regions and aid for certain agriculture, forestry and fisheries issues.

93 Council Regulation (EC) 733/2013 amending Regulation (EC) 994/98 on the application of Articles 92 and 93 of the Treaty establishing the European Community to certain categories of horizontal State aid [2013] OJ L204.
} 


\subsection{The approach of the European Commission}

The Commission aims to ensure that all companies within the EU operate on a level playing field where competitive companies succeed. It ensures that the interventions of Member States do not interfere with the smooth functioning of the internal market or harm the competitiveness of companies within the EU. ${ }^{94}$ It is argued that the Commission has hardened its approach to EU state aid policy and is moving away from a softer form of governance. ${ }^{95}$ It has strengthened its relationship with both EU institutions and national courts, which has driven it towards hardening rule making. ${ }^{96}$ On 8 May 2012, the Commission set out a new approach for reform in the Communication on State Aid Modernisation. ${ }^{97}$ The Commission emphasises among other things that one of the key goals is to prioritise enforcement in cases that have a significant impact on the internal market. Joacquin Almunia, Vice President of the European Commission, stressed in his speech on 8 October 2012 that the objective of the reform was to ensure well-designed aid targeted at identified market failures and objectives of common interest, and to avoid distortion of competition and inadequate support that does not give companies a real incentive, crowds out private investment and supports inefficient and unprofitable companies. In other words, good state aid strengthens the internal market and poor state aid weakens it. ${ }^{98}$ On 22 July 2013, the Council adopted rules to modernise state aid policy, where approval was given for the reform of procedural regulation ${ }^{99}$ which contributes to the Commission's State Aid Initiative. ${ }^{100}$ The reform improves the handling of cases by ensuring that the Commission has all necessary information available by improving cooperation with national courts, gathering information directly from market participants and thus being in a position to conduct sector inquiries. ${ }^{101}$ This will improve the efficiency and effective-

\footnotetext{
94 Europa/European Commission (n 30).

95 Cini (n 29) 204.

96 ibid 205.

97 European Commission Press Release, 'State Aid: Commission Launches Major Initiative to Modernise State Aid Control' (8 August 2012) IP/12/458 < http:/ / europa.eu/rapid/press-release_IP-12-458_en.htm> accessed 30 July 2013.

98 Joaquin Almunia, Vice President of the European Commission responsible for Competition Policy, 'Presenting the Competition Policy Work Programme for 2013/14 ECON' (Speech/12/701 European Parliament, Brussels, 8 October 2012) <http://europa.eu/rapid/press-release_SPEECH-12-701_en.htm> accessed 1 July 2013.

99 Council of the EU Press Release, 'Council Adopts Rules to Modernise State Aid Policy' (Brussels 22 July 2013) 12632/13, (OR. en) PRESSE 343 <http:/ /www.consilium.europa. eu/uedocs/cms_data/docs/pressdata/en/intm/138249.pdf> accessed 2 August 2013.

100 Almunia (n 978).

${ }^{101}$ European Commission Press Release, 'State Aid: Commission Welcomes Council Adoption of Revised State Aid Rules on Block Exemptions and Procedures' (23 July 2013) IP/13/728 <http://europa.eu/rapid/press-release_IP-13-728_en.htm> accessed 1 August 2013.
} 
ness of state aid control and provide the Commission with sufficient tools to tackle important cases which distort competition most significantly. ${ }^{102}$ All this is a clear indication that state aid policy is of high priority for the Commission and leaves the impression that state aid is a matter on which the EU comes down hard.

\subsection{An early assessment}

As I will demonstrate in section 6, monarchies are largely financed by the state through public budgets, especially the Danish monarchy. This raises the question of whether the taxpayer's contribution to the operating of monarchies through state budgets can be considered a parafiscal levy and whether the monarchies are under the control of public authority. Briefly, both the Danish and British monarchies are regulated in national law, which may indicate that they are under the control of the state. Looking closer at royal warrants, it may be argued that they confer an economic advantage on specific undertakings, which was examined in section 3. Further, looking at the nature of monarchies, it may be argued that they are attributable or imputable to the state, which will be considered later during the assessment of whether monarchies are an emanation of the state in sections 5 and 6 . Additionally, as argued by the ECJ, it is essential to determine whether public authorities are involved in monarchies. Even though selection for the award of royal warrants is carried out independently and autonomously by the monarchies themselves, the ECJ has held that EU state aid law will not accept independent institutions 'allocating' aid to circumvent rules on state aid. Thus, royal warrants may be caught by the ECJ's conclusions if monarchies are considered to be an emanation of the state.

Looking at the undertakings that have been awarded royal warrants, the provisions on state aid clearly prohibit aid if it is provided exclusively to certain companies, irrespective of the number of companies. Since the award of royal warrants should not distort competition, it is important to examine the economic impact of royal warrants, as dealt with in section 3. Although it may be difficult to measure if they have any actual effect, the ECJ has held that it should be determined whether aid strengthens the position, especially the financial position, of the undertaking. In other words, the question to be asked is whether the businesses which have been awarded royal warrants are better off compared to their competitors which have not been thus awarded. This will be further examined in section 8. However, a question arises on whether the royal warrants are a kind of aid that is so small that it does not distort competition. Overall, the ECJ has held that any aid, whatever the size, will be capable of distor-

$\overline{102}$ European Commission Press Release (n 101). 
ting competition. Nevertheless, the de minimis aid regulation exempts aid up to a certain amount. And this leads to the question of how to calculate the effect of royal warrants, as already examined in section 3 .

Royal warrants can be considered as 'free' advertising, quality labelling and promotion for those businesses that supply the royal households. To what extent would the effect of royal warrants, in normal situations, be covered by day-to-day management or operation? It should also be considered whether royal warrants affect trade between Member States. Even though it may be argued that royal warrants only affect the domestic market, eg carpenters or flower suppliers, there will still be a breach of the EU provisions on state aid as they can affect businesses from other Member States who seek access to that market. Overall, this leads to the provisional conclusion that royal warrants distort competition and trade between Member States, that they are imputable to the state, that the aid originates from state resources and that the institution of monarchies are under the control of the state.

If we assume that royal warrants are considered state aid, there may still be some derogation from the prohibition. Looking through the derogations from the prohibition of state aid, royal warrants do not, in principle, fall within any of the categories listed in Article 107(2) and (3) TFEU, and therefore cannot be justified there. This indicates that royal warrants are most likely in breach of the EU provisions on state aid. However, there needs to be a case-by-case assessment on whether the award of a royal warrant to a specific business can be justified by the exemption. For example, Carlsberg Brewery has a royal warrant from the Danish monarchy for all its products in the EU, and this campaign/ advertisement/quality label may indeed exceed the de minimis aid regulation exemption of $€ 200,000$. Moreover, breweries are not to be found in any of the GBEs. In general, it is difficult to assess the dimensions of the royal warrant and calculate the actual financial advantage over time as this depends on a case-by-case assessment of the individual undertaking that has been awarded a royal warrant.

These assumptions are still not definite and I will therefore in the following sections discuss the nature of the monarchies of the UK and Denmark, including to what extent they can be considered an emanation of the state and whether they are under the control of public authority. Further, I will assess whether royal warrants fall within the provisions of Article 34 TFEU (free movement of goods) and whether they can be declared incompatible with EU law. 


\section{An emanation of the state}

It is essential to determine whether the monarchies in the UK and Denmark can be considered bodies providing public services under the control of the state and thus be defined as 'an emanation of the state'. Firstly, the Commission has held that state aid control comes into play when services are provided by a company and financed through public resources, in particular because overly generous compensation could enable the service providers to cross-subsidise their other commercial activities, and thereby potentially distort competition. ${ }^{103}$ The task of identifying the state and its various organs or emanations can therefore be a crucial point for individuals seeking to rely on the rights and protections derived from EU law. ${ }^{104}$ Nonetheless, the nature of monarchies is not clear and in order to define whether or not they fall within the scope of 'emanation of the state' it is necessary to outline the case law of the ECJ and of the courts of individual Member States which have dealt with the question in order to identify the straw in the wind. A definition of the concept of state lies in different pieces from various cases of the ECJ.

In Van Duyn and Ratti ${ }^{105}$ it was held that directives can be enforced by individuals against the state in its capacity of the state. Direct effect is limited with regard to directives, and in principle individuals are not able to rely on rights derived from directives (secondary legislation). However, the ECJ dealt with this issue in Marshall $v$ Southampton. ${ }^{106}$ Miss Marshall worked for a public authority and wished to enforce a directive against the state acting in its capacity as her employer. The ECJ stated that individuals may only rely on provisions, such as a directive, in their relation to the 'state' in its capacity as 'employer or public authority', since it is necessary to prevent states from taking advantage of their own failure to comply with EU law. ${ }^{107}$ However, such a provision cannot be relied upon in a case against another individual. ${ }^{108}$ Here, the core is that while the ECJ held that direct effect would allow legal actions based on directives against the state (vertical direct effect), the ECJ accepted that the concept of state could appear in a number of emanations. ${ }^{109}$ It follows from the ECJ:

\footnotetext{
${ }^{103}$ European Commission/Europa, Competition <http://ec.europa.eu/competition/state_aid/overview/public_services_en.html> accessed 21 July 2013.

104 Jennifer Eady, 'Emanation of the State' (1997) 26 ILJ , 249.

105 Case 41/74 Yvonne van Duyn v Home Office [1974] ECR 1337; Case 148/78 Pubblico Ministero $v$ Ratti [1979] ECR 1629.

106 Case 152/84 MH Marshall v Southampton and South West Hampshire Area Health Authority (Teaching) [1986] ECR 723.

107 ibid para 49.

108 ibid para 48.

${ }^{109}$ Eurofound, European Industrial Relations Dictionary, 'Emanations of the state' <http:// www.eurofound.europa.eu/areas/industrialrelations/dictionary/definitions/emanationsofthestate.htm> accessed 9 August 2013.
} 
... where a person involved in legal proceedings is able to rely on a directive as against the state he may do so regardless of the capacity in which the latter is acting, whether employer or public authority. In either case it is necessary to prevent the state from taking advantage of its own failure to comply with Community law. ${ }^{110}$

The ECJ has thereby held that the state may appear in different kinds of emanations. ${ }^{111}$ Whether or not undertakings fall within the scope of 'emanation of the state' is developed though the case law of the ECJ. Before discussing the nature of monarchies in relation to state aid and drawing any conclusions, I will briefly draw attention to cases in other areas of EU law which may offer an analogy to monarchies.

\subsection{Foster $v$ British Gas - defining the concept of State}

In the case of Foster $v$ British Gas, ${ }^{112}$ in which six women who were employed by British Gas prior to its privatisation in 1986 were all forced to retire when reaching the age of 60 , before the date on which the corporation's rights and liabilities were transferred to British Gas under the Gas Act 1986, ${ }^{113}$ the ECJ held that the individuals could rely on a directive against British Gas Ltd as it was an emanation of the state. In Marshall ${ }^{14}$ the ECJ had already ruled that discriminatory retirement ages violate EU law and therefore the core in Foster $v$ British Gas was whether a directive could be invoked in proceedings against a nationalised corporation (horizontal level). ${ }^{115}$ Essential to this case was defining to what extent British Gas could be seen as an organ of the state, and so the ECJ defined the term 'emanation of the state':

... a body, whatever its legal form, which has been made responsible, pursuant to a measure adopted by the state, for providing a public service under the control of the state and has for that purpose special powers beyond that which result from the normal rules applicable in relations between individuals. ${ }^{116}$

By defining the concept of 'emanation of the state', the ECJ has developed three-stage criteria to determine whether a body is an 'emanation

\footnotetext{
110 Marshall $v$ Southampton (n 106) para 49.

111 ibid.

112 Case 188/89 Foster $v$ British Gas Ltd [1990] ECR I-3113.

113 The ECJ ruled that when a state has failed to implement a directive as required, that state should not be allowed to benefit from the failure. Therefore, the provisions of the Equal Treatment Directive (and any other EU directive) can be relied upon against any organisation that is an emanation of the state.

${ }^{114}$ Marshall $v$ Southampton (n 106).

115 Nicholas Grief, 'Direct Effect of Directives and Organs of the State' (1991) 16(2) EL Rev 137.

${ }^{116}$ Foster v British Gas (n 112) para 20.
} 
of the state'. Recalling what was said above, the first requirement is to determine whether there is a control element in the sense that the body is subject to the authority or control of the state. Second, there must be a public service element; and, lastly, there must be a special powers element. ${ }^{117}$ Nevertheless, the ECJ held that it is for the national courts to determine whether the body falls within the scope of an emanation of the state. In Foster $v$ British Gas, the House of Lords decided that the definition was wide enough to cover British Gas (which had been privatised some years earlier) and remitted the case to the Industrial Tribunal for compensation to be assessed. The ECJ concluded that the company was a state controlled body providing a public service. AG Van Gerven sought to define the concept of state in his Opinion in Foster $v$ British Gas ${ }^{118}$ by comparing various cases of the ECJ. He emphasises that the ECJ only distinguished between the concepts of 'state' and of 'individuals' in its case law. He points out that a third classification should be created, which lies within the notorious definition of a body between the two classifications. ${ }^{119}$ AG Van Gerven therefore draws attention to other areas of EU law where there is a notion of public authority and which will help define the concept of state. In the cases Van der Kooy $v$ Commission, ${ }^{120}$ which are highly relevant for this paper as they concern state aid, the ECJ held that no distinction may be drawn between cases where aid is granted directly by the state and cases where it is granted by public or private bodies established or appointed by the state to administer the aid. ${ }^{121} \mathrm{As}$ an example, the ECJ points to concrete indications of public aid, ie when a firm directly or indirectly owns $50 \%$ of the shares in the undertaking, appoints or hires members of the board and where certain decisions on the granting/award of aid have to be approved by ministers. ${ }^{122}$ In this way, the ECJ concluded that the undertaking in Van der Kooy did not enjoy full autonomy, but acted under the instructions of public authorities. ${ }^{123}$ It was thus concluded that the fixing of the contested tariff was the result of an action carried out by the Member State and fell within the concept of '.. aid granted by a Member State for the purposes of article 92 EEC' (now article 107 TFEU). ${ }^{124}$ AG Van Gerven emphasised the following with regard to the ECJ judgment:

\footnotetext{
${ }^{117}$ Eady (n 104) 249.

${ }^{118}$ Foster v British Gas (n 112), Opinion of AG van Gerven.

119 ibid para 10.

${ }^{120}$ Cases 67, 68 and 70/85 Van der Kooy v Commission [1988] ECR 219.

121 ibid para 35.

122 ibid para 36.

123 ibid para 37.

124 ibid para 38.
} 
That definition of the State as the author of aid measures reflects a broad interpretation which corresponds to the purpose of Article 92(1) of the Treaty [now article 107(1) TFEU], that of encompassing all aid measures: 'any aid granted by a Member State or through State resources in any form whatsoever'. ${ }^{125}$

An examination of the selection process and the award of royal warrants (see section 2) does not suggest that the states (Denmark and the UK) instruct the monarchies on whom to select. However, this indication is not exhaustive and there are a number of other cases which deal with the nature of bodies.

The issue of the concept of state was raised shortly after the judgment of Marshall ${ }^{126}$ in Johnston $v$ Chief Constable, ${ }^{127}$ which concerned the possibility for an employee to rely on a directive ${ }^{128}$ against the Chief Constable. The British government refused the complainant's claims and argued that individuals could not rely on the directive, as the Chief Constable was constitutionally independent of the state. ${ }^{129}$ However, the ECJ held the following:

... the Chief Constable is an official responsible for the direction of the police service. Whatever its relation may be with other organs of the State such a public authority charged by the State with the maintenance of public order and safety does not act as a private individual. It may not take advantage of the failure of the State of which it is an emanation to comply with Community law. ${ }^{130}$

Here, the ECJ again emphasises that bodies which have special powers compared with the rules applicable in relations between individuals may not act as a private individual for the reason that the state may not benefit from its own failure to comply with EU law, inter alia, the 'estoppel argument'.

Another area of EU law that may offer an analogy to the nature of monarchies is Directive 2004/18/EC. ${ }^{131}$ Article 1(9) of the directive defines contracting authorities as any body: (a) established for the specific purpose of meeting needs in the general interest, not having an industrial

\footnotetext{
${ }^{125}$ Foster v British Gas (n 112) para 12.

${ }_{126}$ Marshall $v$ Southampton (n 106).

${ }^{127}$ Case 222/84 Johnston $v$ Chief Constable of the Royal Ulster Constabulary [1986] ECR 1651.

${ }^{128}$ Articles 3(1) and 4 of Council Directive (EEC) 76/207 on the implementation of the principle of equal treatment for men and women as regards access to employment, vocational training and promotion, and working conditions [1976] OJ L39/40.

129 Johnston $v$ Chief Constable (n 127) para 49.

130 ibid para 56.

${ }^{131}$ Council Directive (EC) 2004/18 on the coordination of procedures for the award of public works contracts, public supply contracts and public service contracts [2004] OJ L134.
} 
or commercial character; (b) having legal personality; and (c) financed, for the most part, by the state, regional or local authorities, or other bodies governed by public law - or subject to management supervision by those bodies - or having an administrative, managerial or supervisory board, more than half of whose members are appointed by the state, regional or local authorities, or by other bodies governed by public law. Many of these criteria may indicate that monarchies, which in the case of public contract, fall within the concept of contracting authorities, and this points to the fact that they may be an emanation of the state. The monarchies (especially the Danish one) are funded largely by public budgets, which I will touch on in section 6. Additionally, Article 4(5) of the Sixth Council Directive on VAT $T^{132}$ gives us another identification of 'the straw in the wind' of the ECJ's definition of the concept of state. Its wording indicates that the provision is restricted to the activities or transactions in which states, regional and local authorities and other bodies governed by public law engage 'as public authorities'. This is also illustrated in the case law of the ECJ in Carpaneto Piacention and Rivergaro, ${ }^{133}$ where the ECJ held that the provision in question seeks to draw a distinction between the activities of those bodies which are governed by public law and those which are governed by private law. The important distinction here is thus in which capacity the public authority acts: as an authority or as a normal taxable person. ${ }^{134}$ Turning to the core question of this paper, these findings lead to the conclusion that monarchies, in contrast to private individuals, are in large parts subject to public law. Therefore, if one follows the ECJ's reasoning, monarchies must be considered 'emanations of the state'. Furthermore, AG Van Gerven draws attention to case law on Article 30 EC (now 34 TFEU) by raising the Buy Irish case, ${ }^{135}$ which concerns the free movement of goods and may offer an analogy to Foster $v$ British Gas $^{136}$ and, in our case, an analogy to monarchies. The Buy Irish case concerns whether a particular restrictive practice can be ascribed to the authorities. The ECJ held that the restrictive practice could be ascribed to the government, and thus Ireland had failed to comply with its obligations under Article 34 TFEU, although an association governed by private law carried out the actual unlawful act. This case again points to the conclusion that monarchies may be ascribed as public authorities. Furthermore, monarchies, by awarding royal warrants, may indicate ethnocentric campaigning indirectly linked

\footnotetext{
${ }^{132}$ Council Directive (EEC) 77/388 on the harmonisation of the laws of the Member States relating to turnover taxes - Common system of value-added tax: uniform basis of assessment [1977] OJ L145.

133 Joined Cases 231/87 and 129/88 Carpaneto Piacention and Rivergaro [1989] ECR 3233, para 15.

${ }^{134}$ Foster $v$ British Gas (n 112) Opinion of AG van Gerven, para 14.

135 Case C-249/81 Commission v Ireland [1982] ECR 4005.

${ }^{136}$ Foster $v$ British Gas (n 112), Opinion of AG van Gerven, para 15.
} 
to the State. I will touch upon the Buy Irish case and ethnocentric campaigns in section 8 . Nevertheless, it should be noticed that the Opinion of an AG does not have any binding power during the proceeding of the ECJ and is not a valid source of law. However, the Opinion may offer guidance and help to understand important elements of cases in EU law. ${ }^{137}$

The definition of 'emanation of the state' in Fosters $v$ British Gas was reinforced in Kampelmann, ${ }^{138}$ where it was held that a directive:

may, however, be relied on against organizations or bodies which are subject to the authority or control of the State or have special powers beyond those which result from the normal rules applicable to relations between individuals, such as local or regional authorities or other bodies which, irrespective of their legal form, have been given responsibility, by the public authorities and under their supervision, for providing a public service ... ${ }^{139}$

Nevertheless, one must be cautious when considering whether or not an organisation is truly an 'emanation of the state' since the ECJ gave the national courts the competence to decide whether or not an undertaking falls within the concept of state. Thus, it is appropriate to examine the Danish and British courts' definition of 'state' in the case law of the national courts. Apparently, the Danish courts have never had any cases dealing with the question of the concept of state. On the other hand, the Court of Appeal in England dealt with the question of 'emanation of the state' in the case of Doughty $v$ Rolls Royce, ${ }^{140}$ where the court held that although the state owned Rolls Royce in its entirety it could not be recognised as an 'emanation of the state'. Rolls Royce could not be considered to be providing a public service and did not therefore satisfy the three criteria given by the ECJ in Foster $v$ British Gas. The crucial test here was not whether the undertaking in its entirety was owned by the state, but whether the body was an organ or agent carrying out a state function. ${ }^{141}$

British Gas was providing a public service under the control of the state and thus it was considered that it had special powers beyond those resulting from the normal rules applicable in relations between individuals, eg powers to acquire land and break up streets and bridges. ${ }^{142}$ This may also concern other undertakings in similar contexts, such as electricity providers, water/wastewater treatment plants, etc. And as Nicholas

\footnotetext{
137 De Burca \& Others, EU Law: Text and Materials, (5 $5^{\text {th }}$ edn, Oxford University Press 2012) 62.

138 Joined Cases C-253/96 and C-258/96 Kampelmann [1997] ECR I-6907.

139 Kampelmann (n 1388) para 46.

140 Doughty v Rolls-Royce [1992] ICR 538, [1992] IRLR 126 (CA).

${ }^{141}$ Andrew C Geddes, 'Foster v British Gas: Widening the Field of Direct Effect' (1990) 140 NLJ 1611.

${ }^{142}$ Grief (n 115) 143.
} 
Grief emphasises, '... so much for the view that Foster would only be of limited application'. ${ }^{143}$ AG Van Gerven held in his Opinion that it is arguable whether universities have special powers as they have the competence to award degrees ${ }^{144}$ even if they are not under state control. Similarly, it can be argued that monarchies have special powers beyond those resulting from normal rules applicable to relations between individuals. For instance, the Danish royal family is not accountable to the Danish courts and the monarch (Her Majesty the Queen Magrethe II) exclusively has the competence to judge members of the royal family for committing any crimes or offences pursuant to the Danish Constitution. ${ }^{145}$ Furthermore, in terms of formal 'political power', she technically appoints the Prime Minister. ${ }^{146}$ The monarch (Her Majesty Queen Elizabeth II) in England holds four constitutional powers, ${ }^{147}$ and thus has, in comparison to the Danish monarch, a higher degree of actual political influence and power.

The Foster ruling was touched upon again in another British case, Griffin $v$ South West Water Services $L t d,{ }^{148}$ in which the national court held that a post-privatised water company should be considered an 'emanation of the state' in a claim relying on an EU directive. The English court broadened the definition of the concept of 'state' and held that the question of control given in the Foster test was to be decided with reference not to whether the body concerned was under the control of the state, but rather whether the public service provided by the company was under the control of the state. ${ }^{149}$ Overall, this indicates that the three criteria set by the ECJ, as mentioned above, in Fosters $v$ British Gas are cumulative. ${ }^{150}$ Geddes argues that in order to assess whether an undertaking is an emanation of the state it is necessary to carry out a careful investigation of the constitution, powers and financial structure of the public undertaking concerned in order to establish whether the 'state' is capable of exercising such influence over its conduct that it can be said to 'control' the undertaking within the definition provided by the ECJ in Foster $v$ British Gas. ${ }^{151}$ As mentioned earlier, monarchies are mentioned in the written and uncodified constitutions of Denmark and the UK respectively and have powers beyond those resulting from the normal rules applicable to relations between individuals. This indicates that monarchies are an 'emanation of the state', pursuant to the Foster ruling.

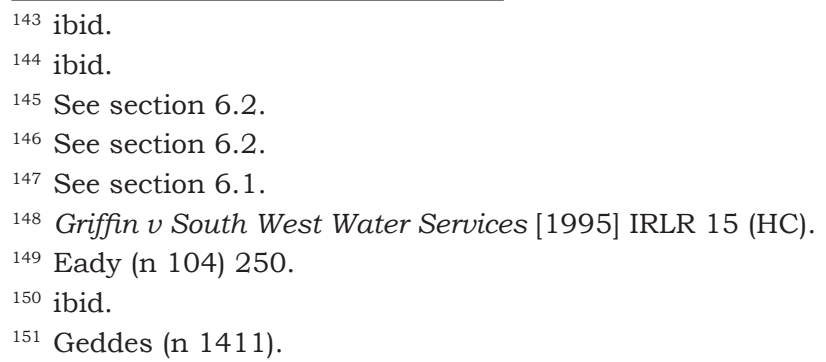




\subsection{The British approach - NUT $v$ St Mary's Church of England Scho- ol}

Another case of EU law that may offer an analogy to the nature of monarchies is National Union of Teachers $v$ St Mary Church of England School, ${ }^{152}$ which concerned the transfer of teachers upon the opening of a new school. Most of the teachers had successfully obtained work at the new school, although three teachers were dismissed for reasons of redundancy on the day the old school closed. The dismissed teachers and the National Union of Teachers relied on an EU Directive ${ }^{153}$ and argued that the governing body of a voluntary aided school was an 'emanation of the state' and that the directive was therefore directly enforceable in this context. However, the English Employment Appeal Tribunal, which dealt with the case, rejected the argument, as the school did not meet the three criteria laid down by the ECJ in Foster $v$ British Gas. Nonetheless, the case went to the Court of Appeal which did not agree with the decision of the Employment Appeal Tribunal. The Court of Appeal referred to the ECJ's previous ruling in Fratelli Constanzo ${ }^{154}$ where the ECJ held that the concept of an 'emanation of the state' is very broad and covers all organs of administration, including decentralised authorities such as municipalities. Thus, the Court of Appeal concluded that there was no exclusive formula, and nor did the ECJ, with the guidance of Foster $v$ British Gas, try to set any fixed route for a decision on an 'emanation of the state'. Interestingly, the Court of Appeal instead looked at the ECJ's reasoning in Marshall, ${ }^{155}$ where it was held that individuals can rely on a directive against a Member State, as Member States should not benefit from their own failure to comply with EU law ${ }^{156}$ - the 'estoppel argument'. ${ }^{157}$ In general, voluntarily aided schools are by their nature established, and to some extent controlled, by the Church. Nonetheless, the state relies on these institutions to supply education to citizens in particular areas of the country. The Court of Appeal held that voluntarily aided schools rely on local education authorities as they cover most of the expenses in running the school, including teachers' salaries, etc, and therefore have a very considerable degree of control and influence over such schools. ${ }^{158}$ In other words, the state may appear in a number of 'emanations' and

\footnotetext{
${ }_{152}$ National Union of Teachers and others $v$ Governing Body of St Mary's Church of England (Aided) Junior School and others [1997] IRLR 242; [1997] ICR 334 (CA).

${ }^{153}$ Council Directive (EEC) 77/187 on the approximation of the laws of the Member States relating to the safeguarding of employees' rights in the event of transfers of undertakings, businesses or parts of businesses (Acquired Rights Directive) [1977] OJ L61.

${ }_{154}$ Case 103/88 Fratelli Constanzo $v$ Comune di Milano [1989] ECR 1839, para 31.

155 Marshall $v$ Southampton (n 106).

156 ibid para 49.

${ }_{157}$ Eady (n 104) 252.

${ }^{158}$ Eady (n 104) 251.
} 
whether or not undertakings, bodies or organisations fall within the scope of the different emanations of the state depends on the criteria laid down and defined by the ECJ through case law. Drawing parallels with this and the case of monarchies where a large part of the funding derives from taxation, and looking back at the definition of Article 107 TFEU and state resources in section 4 , these findings may indicate that the conduct of monarchies are attributable to the state, even though they are independent and enjoy full autonomy in the selection and awarding of royal warrants.

The above-mentioned cases and legislation may not deal directly with the provisions on state aid or free movement of goods (which will be covered later in section 7), but they still give an idea of how to define 'emanation of the state' in other EU provisions and how national courts, especially British courts, apply the definition and this may therefore be analogically transferred to the concept of state in other areas of EU law.

\subsection{The approach of the European Commission}

Finally, the criteria that may bring a public body within the scope of the concept of state according to the Commission should be examined. However, there is not much information from the Commission on the definition of public bodies. In his Opinion in Foster $v$ British Gas, AG van Gerven outlined some of the Commission's criteria that may bring a public body under the concept of state. There is the criterion of 'carrying out a public function on behalf of the state', which covers public corporations established to run nationalised industries (such as British Gas Ltd), public bodies which exercise regulatory powers, and universities which award degrees recognised by the state. ${ }^{159}$

It has been argued that the legal form of 'emanation of the state' is irrelevant as long as it is responsible for providing a public service under the control of the state and has been awarded special powers for that purpose. ${ }^{160}$ This could include privatised industries or services, which formerly provided public services.

So, what does all this tell us about monarchies? The overall assessment indicates that monarchies do have special powers, both legal and political: they act as state officials, are largely funded by the state and are governed by public law. All this indicates that they are an emanation of the state.

\footnotetext{
${ }_{159}$ Case C-189/89 Foster v British Gas [1990] ECR I-3313, Opinion of AG van Gerven para 20.

${ }^{160}$ Eurofound (n 109).
} 


\section{Monarchies' political role and effect on the state}

Historically, monarchies have had great influence on the political, legal and executive agenda of states. In order to define the role of monarchies in the modern states of the UK and Denmark, it is essential to examine their legal nature, allocation of powers and their assignments as state representatives. It is further necessary to assess these factors as this may help to clarify whether the British and Danish monarchies are 'emanations of the state' in an EU Member State and thereby subject to applicable EU legislation on state aid and free movement of goods.

\subsection{Monarchy in the United Kingdom}

In the 'uncodified' Constitution ${ }^{161}$ of the UK, the monarch (also known as the Crown or Her Majesty the Queen) is the head of state. ${ }^{162}$ The monarch holds four key constitutional powers (royal prerogatives) and it is exclusively the Queen who may exercise these powers. ${ }^{163}$ Firstly, the Queen has the power to legally appoint whoever she desires to be the Prime Minister of the UK and likewise she could keep the position vacant. Historically, the Queen exercised this power in 1957 and 1963. ${ }^{164}$ Secondly, the Queen has the power to dissolve Parliament at any time, for any reason, or for none. ${ }^{165}$ The power was last exercised in the UK in 1834; however, it was exercised in Australia in 1975 and in Canada in 2008. ${ }^{166}$ However, the power was revised in the Parliament Act of 2011. Likewise the Queen has the power to dismiss the government at any time for any reason, and cannot be challenged in a national court. ${ }^{167}$ The Queen has the power to withhold royal assent to legislation passed by the Houses of Parliament. A bill cannot become a legally binding Act of Parliament unless it receives the royal assent. ${ }^{168}$ In other words, the Queen has de facto veto power on all legislation passed by the parliament,

\footnotetext{
${ }^{161}$ The British Constitution is unwritten or, in other words, 'uncodified'. This means that in contrast to most modern democracies, there is no single document which explains how the United Kingdom is governed. Instead, the Constitution consists of a number of treaties, laws and conventions, which together make up the constitution.

162 Vernon Bogdanor, 'The Monarchy and the Constitution' (1996) 49(3) Parliamentary Affairs 407.

${ }^{163}$ Republic, 'The British Constitution' < http://www.republic.org.uk/What\%20we\%20 want/In\%20depth/The\%20British\%20Constitution/index.php> accessed 25 August 2013. 164 ibid.

165 ibid.

166 The Queen exercised her power to dismiss parliament in Australia, where the Queen's appointed representative dismissed the democratically elected government of the day in 1975 and, furthermore, in Canada where the Queen's appointed representative prorogued parliament for several weeks in late 2008, preventing it from performing its democratic and constitutional functions, Republic (n 1633).

167 Republic (n 1633).

168 VRAC Crabbe, Understanding Statutes (Cavendish Publishing 1994) 17.
} 
and she is not required to give any reason for withholding her assent. ${ }^{169}$ Furthermore, the monarch has royal prerogatives in various areas, which in theory are vested in the Crown. However, it should be noticed that in practice they are vested in the government. These royal prerogatives consist of the powers to sign treaties, to declare war and to deploy overseas Her Majesty's Armed Forces, to employ civil servants and to change the terms and conditions of their employment, the conduct of diplomacy, the governance of Britain's overseas territories, the appointment and removal of ministers, the appointment of peers, the granting of honours and the granting and revoking of passports. ${ }^{170},{ }^{171}$ The Queen also possesses judicial powers as she is the 'source of justice' and the courts belong to the Queen. ${ }^{172}$ Furthermore, she exercises various functions through the Attorney General and the Lord Advocate, ie pardoning convicted persons, offenders or remitting or reducing sentences, granting special leave to appeal to the Judicial Committee. ${ }^{173}$ Lastly, it should be mentioned that the Queen herself has legal immunity, as the Crown Proceeding Act 1947 only allows legal proceedings against the Crown in its public capacity (ie against the government) and this quite remarkably means that no lawsuits may be instituted against the Crown personally; in other words the Crown has legal immunity.

Bogdanor argues that these 'formalities' have little substance today, as the prerogative and legal powers of the Crown are exercised not by the Queen personally, but on the advice of ministers or by ministers directly. ${ }^{174}$ On the other hand, Ben Pimlott ${ }^{175}$ argues that the Queen's political influence is played out behind the scenes and is always subtle. The author draws attention to historical events where the Queen has expressed her political view. For example, the Queen questioned the merits of the British invasion of Suez in $1956^{176}$ and expressed her strong disagreement of the government's support for the US invasion of Grenada in 1983. ${ }^{177}$ She also expressed her view that the Thatcher government should be more caring towards the poorer Commonwealth countries ${ }^{178}$ and

\footnotetext{
169 Bogdanor (n 1622) 413.

170 Republic (n 1633).

${ }^{171}$ Lucinda Maer and Oonagh Gay, 'The Royal Prerogative' (2005), Parliament and Constitution Centre, House of Commons Library 3.

172 ibid 4.

173 ibid (n 1711) 2.

174 Bogdanor (n 1622) 414.

${ }^{175}$ Ben Pimlott, former professor of politics and contemporary history at Birkbeck College, London University.

176 Ben Pimlott (1996), The Queen: A Biography of Queen Elizabeth II (Harper Collins Publishers, 1996) 253.

177 ibid 496-497.

178 ibid 501.
} 
in 1986 she expressed concern to Margaret Thatcher on British sanctions on South Africa. ${ }^{179}$ She also expressed her doubts about the decision to allow the Americans to use British airbases for a raid on Libya in April 1986. ${ }^{180}$ Pimlott criticises the Queen for her role in the handover of power between the Tory Prime Ministers Harold Macmillan and Alec Douglas-Home. ${ }^{181}$ She allowed Macmillan to fool her into becoming a political pawn, described by Pimlott as '... the biggest political misjudgement of her reign'. ${ }^{182}$ As a result of 'the Macmillan-Home debacle'183 the Conservatives changed their method of selecting their leader. ${ }^{184}$ This effectively put an end to the monarch's discretionary power of choosing the Prime Minister in normal circumstances. Nonetheless, Pimlott argues that the manoeuvrings around the formation of the minority Labour government in 1974 indicated that the monarch still retained a significant role, and the author goes on to state that though '... the Queen's prerogative powers were never invoked', ${ }^{185}$ there is the belief that they could be played out in a political battle. ${ }^{186}$ In sum, the British monarch has special powers beyond that of a 'normal' individual as she represents the state on various occasions and has exercised political influence in the UK a number of times. Therefore, it can be concluded that the monarchy in the UK is an emanation of the state.

\subsection{Monarchy in the Kingdom of Denmark}

In accordance with $\S 2$ of the Danish Constitution, Grundloven, ${ }^{187}$ the form of government is a constitutional monarchy. Under $\S 3$ Grundloven it is determined that legislative power is vested in both the monarch and parliament together and executive power is vested in the monarch. The monarch in Denmark cannot be prosecuted for any criminal offences, pursuant to $\S 13$. The monarch has the power to refuse or approve a bill by royal assent pursuant to $\S 22$, and the power to dismiss and appoint ministers and the Prime Minister pursuant to $\S 14$. Besides this, the monarch is mentioned in several paragraphs of the Constitution under the term "The King" (Kongen). Nonetheless, it is argued that the Grundloven

\footnotetext{
179 ibid 505.

180 ibid 508.

181 ibid 324.

182 ibid 335.

183 ibid 536.

184 Paul Vallely, 'Queen's Politics Revealed' The Independent (London, 3 October 1996) <http://www.independent.co.uk/news/queens-politics-revealed-1355324.html> accessed 21 August 2013.

185 Pimlott (n 1766) 423.

186 ibid 423.

187 The Constitutional Act of Denmark, Grundloven, was agreed on in 1849 and revised in 1953.
} 
should be interpreted in the context that 'The King' in practice designates the Prime Minister, as the Danish parliament and government would otherwise constantly violate the Constitution. Although it may seem that the Constitution provides powers to the monarch, reality is different as legislative power is vested exclusively in parliament and executive power is vested in the government. The monarch still formally approves all new governments, but the procedure is merely a formality, and compared to the British circumstances the Danish monarch has no say in this context. Nevertheless, the royal family still has an important role and influence in the state of Denmark as it acts as representatives and officials of the state domestically and internationally. Jens Høvsgaard, a journalist, emphasises that the Queen has a special position in Danish society due to the fact that she is not accountable to the law. ${ }^{188}$ Furthermore, with regard to the monarchy's connection with the state, it is important to draw attention to the fact that the royal family receives annual funds, 'apanage', from the Danish state and is established by law. ${ }^{189}$ Jens Høvsgaard argues that the Queen is Denmark's head of state and her family is the country's official representatives ${ }^{190}$ and the Queen's statements represent the official position of Denmark on her official visits to foreign countries. ${ }^{191}$

Below, I will outline a few recent examples to support the hypothesis that the Danish royal family represents Denmark as state officials. Firstly, the Danish Queen has, on several occasions, awarded the 'cross of the order of chivalry' to state leaders such as Nicolae Ceausescu, Haile Selaisse, King Fahd and Hosni Mubarak. ${ }^{192}$ Recently, shortly before the 2011 revolts in Bahrain, the Queen awarded the 'Knight's Cross of the Order of the Dannebrog' to King Hamad ibn Isa Al Khalifa, which was an unfortunate situation as it could be seen as an illustration of Danish state support for a dictatorship. In that respect, it has been publicly discussed whether the Queen on her own initiative decided to award the Order or whether the Danish Ministry of Foreign Affairs was responsible for this decision. ${ }^{193}$ The Ministry of Foreign Affairs stresses that it is the monarchy and not the government that is responsible for the award of the Orders. ${ }^{194}$ However, Lene Espersen, ${ }^{195}$ Minister of Foreign Affairs, stated the award of the Orders is decided between the royal court and the mi-

\footnotetext{
${ }^{188}$ Høvsgaard (n 20) 163.

189 Lov nr. 491 af 7. Juni 2001 om Dronning Margrethe den Andens civiliste (Civillisteloven).

190 Høvsgaard (n 20) 250.

191 ibid 69.

192 ibid 62.

193 ibid 68.

194 ibid 74.

195 Lene Espersen is Member of Parliament for the Conservative People's Party in Denmark and was Danish Minister of Foreign Affairs from 23 February 2010 to 3 October 2011.
} 
nistry. ${ }^{196}$ Jens Høvsgaard emphasises that this might be problematic as the Queen and her activities should be apolitical. ${ }^{197}$ This points to the fact that the awarding of orders is a grey zone between the government and the monarchy and that the Queen therefore may have a certain degree of political influence. Zenia Stampe, ${ }^{198}$ Member of the Danish Parliament, in the case of the awarding of an Order to King Hamad ibn Isa Al Khalifa, argued that: 'Awarding Orders is a special and very valuable political privilege'. ${ }^{199}$ She thus argues that the Queen holds an important political tool in awarding Orders, and in the given case represented Denmark's official position on the human rights situation in Bahrain. Surely this indicates, irrespective of whether or not the Queen autonomously decided to award the Order, that the Queen represents the state's official position. Compared to the British monarchy, the Danish one does not have or exercise many powers. However, critics still argue that the royal family in Denmark executes important political actions when representing the state of Denmark. Financially, politically and legally, all facts strongly point to the conclusion that the monarchies of the UK and Denmark have state powers beyond those of individual persons and that they in certain cases influence the political practices of the state. This examination therefore indicates that these monarchies by their very nature are 'emanations of the state'.

\section{Free movement of goods}

In order to examine the case of royal warrants, the area of the free movement of goods also needs to be outlined. Case law of the ECJ has shown that campaigns promoting national products constitute a breach of the substantive right of free movement of goods. The following will include only the relevant provisions and case law in relation to the effect of royal warrants on the internal market from the perspective that they affect the companies from other Member States who wish to operate on the Danish or British domestic markets. According to the TFEU, the provisions on goods apply to 'Member States'. This definition of state is broadly defined and includes central and local government. Additionally, the Treaty provisions on goods also applies to professional regulatory bodies and private bodies supported by the state, whether through finance or other forms of supervision, ${ }^{200}$ which will be examined in section 8 .

\footnotetext{
196 Høvsgaard (n 20) 73.

197 ibid 69.

${ }^{198}$ Zenia Stampe is Member of Parliament for the Social Liberals in Denmark.

199 Zenia Stampe 'Så stands dog diktatorstøtten' (2011) <http://www.radikale.net/zeniastampe/indlaeg/2011/06/25/saa-stands-dog-dronningens-diktatorstoette> accessed 15 August 2013.

200 Catherine Banard, The Substantive Law of the EU: The Four Freedoms (3 ${ }^{\text {rd }}$ edn, OUP
} 


\subsection{Legal basis}

Article 34 TFEU prohibits quantitative restrictions on imports and measures having equivalent effect (non-tariff barriers). There is no definition of the term quantitative restrictions in the TFEU, but it is generally accepted that they should be understood as any limitations in terms of the quantity of goods subject to import or even export. In the Dassonville case, ${ }^{201}$ the ECJ formulated the 'Dassonville formula' which states that '... all trading rules enacted by Member States which are capable of hindering directly or indirectly, actually or potentially, intra-community trade are to be considered as measures having an effect equivalent to quantitative restrictions'. ${ }^{202}$

In Commission $v$ Italy, ${ }^{203}$ the ECJ defined measures having equivalent effect as follows:

... measures adopted by a Member State the object or effect of which is to treat products coming from other Member States less favourably are to be regarded as measures having equivalent effect to quantitative restrictions on imports within the meaning of Article [34 TFEU], as are the measures referred to in paragraph 35 of the present judgment. Any other measure which hinders access of products originating in other Member States to the market of a Member State is also covered by that concept. ${ }^{204}$

In Prantl, ${ }^{205}$ the ECJ held that in order to constitute a breach of Article 34 TFEU:

... it is sufficient that the measures in question are liable to impede, directly or indirectly, actually or potentially, trade between the member states. It is not necessary that they should have an appreciable effect on intra-community trade.

Furthermore, in the famous case Buy Irish, ${ }^{206}$ the ECJ held that the effect of the campaign was not essential, but instead emphasised the seriousness of the discriminatory purpose of the campaign, which was capable of affecting trade relations between Member States. The case will be explained in subsection 8.1 .

\footnotetext{
2010) 35 .

201 Case 8/74 Dassonville [1974] ECR 837.

202 ibid para 5.

203 Case C-110/05 Commission v Italy [2009] ECR I-519.

204 ibid para 37.

205 Case 18/83 Prantl [1984] ECR 1299, para 20.

206 Case 249/81 Commission v Ireland (Buy Irish) [1982] ECR 4005, para 25.
} 


\section{Ethnocentric campaigns affecting the internal market}

Campaigns aiming to increase ethnocentrism are often framed as a desire to 'support our own', especially in times of economic hardship, ${ }^{207}$ such as the on-going financial crisis, where it may be difficult for states to act with fairness in the internal market. 'Buy national' campaigns are by their nature intended to encourage consumers to purchase national products in preference to imported goods. Boosting ethnocentric consumer behaviour may contravene the principles of the EU internal market and undermine the hard and long process of integration of the EU single market and removal of age-old barriers between states. ${ }^{208}$ This leads to the question of whether royal warrants can be defined as ethnocentric campaigns. I will examine this definition both from the perspective of the free movement of goods and state aid and whether there is a relation between the two areas in terms of ethnocentric campaigns.

\subsection{The Buy Irish campaign}

Janja Hojnik describes some of the various so-called 'ethnocentric campaigns of EU member states' that promote national products. ${ }^{209}$ Ethnocentric campaigns on EU territory have been carried out for years. In the famous Buy Irish case, ${ }^{210}$ the Irish government tried to encourage its own nationals to buy Irish rather than imported goods. The ECJ stated that the association's campaign was '... a reflection of the Irish government's considered intention to substitute domestic products for imported products on the Irish market and thereby to check the flow of imports from other Member States ${ }^{211}$ and declared that the campaign did constitute measures having effect equivalent to quantitative restrictions on imports pursuant to Article 34 TFEU. The ECJ held that Ireland had failed to fulfil its obligations under EU law by organising a campaign promoting its own national goods within its territory. ${ }^{212}$

\subsubsection{Opinion of Advocate General Capotorti - state aid versus free move-} ment

While the ECJ concluded that Buy Irish was an infringement of the free movement of goods, AG Capotorti in his Opinion emphasises a noteworthy view contrary to the ECJ:

\footnotetext{
${ }^{207}$ Robert P Williams, 'Combating Economic Protectionism in the EEC: The Buy Irish Case' (1983) 13(2) Georgia Journal of International \& Comparative Law 590.

208 Janja Hojnik, 'Free Movement of Goods in a Labyrinth: Can Buy Irish Survive the Crisis?' (2012) 49 CML Rev 301-302.

209 ibid.

${ }^{210}$ Case 249/81 Commission v Ireland (Buy Irish) [1982] ECR 4005.

${ }^{211}$ ibid para 23.

212 ibid para 35.
} 
In the present case it seems clear to me that the contested activities are in the nature, not of barriers or obstacles to trade established by the public authorities, but rather of public aid whereby it is sought to give domestic producers a competitive advantage over foreign producers. ${ }^{213}$

In his argumentation, AG Capotorti draws attention to Commission $v$ France, ${ }^{214}$ in which the ECJ held that under Article 92 EEC (now 107 TFEU) the Member States agreed that any aid granted by them in any form whatsoever which distorts or threatens to distort competition is incompatible with the internal market. ${ }^{215}$ By linking the latter case to Buy Irish, AG Capotorti emphasises that the advertised campaign in Ireland was inspired and financed by the Irish government and thus, in his opinion, clearly constitutes a case of state aid under Article 92 EEC. ${ }^{216}$ As mentioned in section 3 on the economic impact of royal warrants, AG Capotorti draws attention to the fact that the Irish campaign takes the advertising initiatives from Irish companies and covers the expenses that the same marketing would have lawfully cost the Irish companies, which places the Irish companies in an advantageous position to their competitors from other Member States, thereby distorting competition in the internal market '... in so far as the burden of paying for the advertising is borne by an institution closely linked to the state'. ${ }^{217}$ This is supported by Robert P Williams who emphasises that foreign companies may suffer from ethnocentric campaigns if consumers withdraw their support for a foreign product in favour of a national product. ${ }^{218}$ Royal warrants may not necessarily be awarded on the governments' initiative, as AG Capotorti argues in his Opinion in the case of Buy Irish. Nevertheless, as has been emphasised in section 5, monarchies are most likely an 'emanation of the state' (or at least largely financed by public money, which AG Capotorti also draws attention to in his Opinion on the Irish Goods Council), which is an indication that royal warrants fall within the scope of the EU provisions on state aid. However, it should be mentioned that the ECJ did not follow AG Capotorti's Opinion that the Commission in Buy Irish should have followed the procedure laid down under Article 93 EEC (now Article 108 TFEU on state aid) and not the provision on the free movement of goods. Still, the Opinion of AG Capotorti is an interesting observation and highlights the relation between state aid and the free movement of goods in cases of ethnocentric campaigns, which may offer an analogy to royal

\footnotetext{
${ }^{213}$ Buy Irish (n 2100) Opinion of AG Capotorti, para 6.

${ }^{214}$ Commission v France (n 68).

215 ibid para 18.

${ }^{216}$ Buy Irish (n 2100) Opinion of AG van Gerven para 7.

217 ibid.

${ }^{218}$ Williams (n 20707) 592.
} 
warrants. It is therefore necessary to examine what the ECJ has held in other areas, since AG Opinions are not a valid legal source, in order to arrive at a conclusion on royal warrants. ${ }^{219}$

Similarly to Buy Irish, the Greek government launched a campaign shortly after the Irish one to promote national products by offering a special discount on Greek products. ${ }^{220}$ However, the Greek campaign did not have any legal consequences. Nevertheless, the judgment of Buy Irish does indicate that campaigns, in which a Member State promotes products produced on its own territory, can been seen as a measure of having equivalent effect to quantitative restriction. Transferring this to the question of royal warrants, which is not directly or obviously a campaign for domestic products as the famous Buy Irish case was, but rather a prestigious label of quality provided to selected companies supplying to the royal households. In order to assess whether an element of an ethnocentric campaign exists in royal warrants as it does in Buy Irish, it is necessary to examine the case law on quality labels and to discover whether there is a relationship between the companies who are awarded royal warrants and the nationality of the companies.

\subsection{Quality labelling}

It may be argued that a royal warrant may represent a quality label for those companies that are awarded it and may have a positive effect on the business and thus an impact on the internal market. ${ }^{221}$ Especially relevant in relation to the discussion on royal warrants and whether they represent a quality label, a German state-sponsored body, Centrale Marketing-Gesellschaft, in 1993 made a quality label exclusively for products produced in Germany, ${ }^{222}$ which was not well received by the ECJ which held that quality marking was also bound by Article $34 \mathrm{TFEU}^{223}$ on the grounds that it had potentially restrictive effects on the internal market. ${ }^{224}$ Furthermore, the ECJ held that a scheme which promotes domestic goods produced in Germany might encourage consumers to buy products with the quality label rather than imported products without the label. ${ }^{225}$ It follows from this that royal warrants may have the same effect on consumers when they choose between domestic products with a royal warrant and foreign products without similar quality labelling. Examples

\footnotetext{
219 De Burca \& Others (n 1377) 62.

${ }^{220}$ Hojnik (n 20808) 298.

${ }^{221}$ Buy Irish (n 2100) Opinion of AG Capotorti para 7.

${ }^{222}$ Hojnik (n 20808) 299.

${ }^{223}$ Case C-325/00 Commission v Germany [2002] ECR I-9977, para 18.

${ }^{224}$ Hojnik (n 20808) 306.

${ }^{225}$ Commission $v$ Germany (n 2233) paras 23-24, where the Court refers to Case C-13/78 Eggers [1978] ECR 1935, para 26.
} 
of similar cases have previously occurred in the EU. In 1995 the Austrian Ministry of Agriculture introduced a quality seal showing food that had been produced in Austria and that was of the highest level of quality. ${ }^{226}$ This did not sit well with the Commission which in 2012 initiated proceedings under Article 108(2) TFEU against Austria. ${ }^{227}$ The case is pending. An Italian company, Buonitalia SpA, founded by the Italian government in 2003, issued quality labels for products exclusively made in Italy, ${ }^{228}$ but there have been no proceedings against Italy. This raises the question of whether private companies and different kinds of public body and, in this case, monarchies, should be considered an emanation of the state. Our assessment in section 5 indicates that monarchies do fall within the concept of state. Just like the Italian government, back in 1961, the French government co-financed a company, Sopexa, which promoted and advertised French food, wine and l'art de vivre. ${ }^{229}$ However, like Buonitalia SPA, Sopexa has never been under the spotlight of the ECJ, ${ }^{230}$ and the Commission's practice is therefore unclear. Janja Hojnik emphasises the importance of the sponsor's role in the campaign. ${ }^{231}$ Accordingly, it is necessary to distinguish between whether it is a private company or the state that funds the campaign to promote goods. It follows from Article 34 TFEU that it only applies to state measures which affect the free movement of goods between Member States. ${ }^{232}$ Hence, it can be derived that only campaigns in which the state is involved, including campaigns by central and regional authorities, are covered by Article 34 TFEU. ${ }^{233}$ In the case of Apple and Pear Development Council'34 and the 'Buy British Fruit' campaign, the ECJ held that a government-supported body, such as the Development Council, is under the duty not to advertise for the purpose of discouraging the purchase of products of other Member States, nor to disparage those products in the eyes of consumers or to advise consumers to purchase domestic products solely by reason of their national origin. Nonetheless, the ECJ stated that Article 30 EEC (now Article 34 TFEU) does

\footnotetext{
${ }^{226}$ Hojnik (n 2088) 299.

227 The European Commission has initiated proceedings under Article 108(2) TFEU regarding AMA marketing measures (state aid SA 15836 (2012 / C) against Austria, by letter dated 12 June 2012.

${ }^{228}$ Hojnik (n 2088) 299.

229 ibid 299-300.

${ }^{230}$ Furthermore, a written question on the legality of Sopexa has been given to the Commission: Written question and answer No 624/81 by Mr Pearce to the Commission: Sopexa [1981] OJ C283, 7. Nevertheless, neither the European Commission nor the Council has answered the question.

${ }^{231}$ Hojnik (n 208) 302.

232 Hojnik (n 20808) 302 and Banard (n 2000) 35.

${ }^{233}$ Case 45/87 Commission v Ireland (Dundalk Water Supply) [1988] ECR 4929; Case C-1/90 Aragonesa de Publicidad v Departamento de Sanidad [1991] ECR I-4151.

${ }^{234}$ Case 222/82 Apple and Pear Development Council v Lewis [1983] ECR 4083, para 18.
} 
not prevent such a body in its publicity from drawing attention to specific qualities of fruit grown in the Member State in question, or from organising campaigns to promote the sales of certain varieties, even if those varieties are typical of national production. ${ }^{235}$ Catherine Banard emphasises that this highlights the ECJ's approach to what it considers the unlawful state-sponsored promotion of national goods and what it considers to be the permissible state-sponsored promotion of specific goods having distinctive qualities. ${ }^{236}$ The Hungarian government has also established a 'helping hand' to promote and advertise Hungarian products in domestic and export markets. ${ }^{237}$ Furthermore, it has also introduced a quality label entirely for Hungarian products in order to make them stand out from other products. The Czech Republic, Slovenia, Lithuania and even Croatia (which at the given time was an acceding country to the EU) have also introduced quality labels and promotions of national products. ${ }^{238}$ Ethnocentric market campaigning therefore seems an on-going tendency and a particularly well-used tool by national governments during financial crises. ${ }^{239}$ Furthermore, it is important to draw attention to the fact that the monarchies in Denmark and the UK serve as state officials, with the Queen of Denmark and the Queen of England positioned as Head of State pursuant to the constitutions, and the royal families in general representing the state on various occasions. ${ }^{240}$ Thus, their acts, ie their awarding of royal warrants, may constitute public statements of officials representing the state's point of view and may be a potential breach of EU law. In the case of AGM-COS.MET Srl $v$ Suomen valtio in Tarmen Lehtinen ${ }^{241}$ the ECJ held that states are responsible for the public statements of their officials who reflect the state's official point of view, regardless of whether they have a binding effect or not. Furthermore, as emphasised by Janja Hojnik, ethnocentric campaigns are full of public statements ${ }^{242}$ and are incompatible with EU law. This is not just an interesting conclusion by the ECJ in relation to Article 34 TFEU, but also an indirect supplement to the ECJ's definition of 'emanation of the state' in the Fosters $v$ British Gas case mentioned earlier in this paper.

\footnotetext{
235 ibid para 19.

236 Banard (n 2000) 83.

237 Hojnik (n 208) 300.

238 ibid.

239 ibid 293.

240 See section 6.

${ }^{241}$ Case C-470/03 AGM-COS.MET Srl $v$ Suomen valtio in Tarmen Lehtinen [2007] ECR I-2749.

242 Hojnik (n 20808) 303.
} 


\subsection{Discrimination}

In Buy Irish, ${ }^{243}$ the ECJ clearly held that it prohibits campaigns which discriminate against products from other Member States. The list of companies awarded royal warrants by the Danish monarchy is composed significantly of Danish companies, with only 8 foreign suppliers. ${ }^{244}$ Looking to the neighbouring monarchy, the British list of suppliers is much more diverse with regards to the nationality of suppliers. For example, suppliers such as French champagne makers and Swedish match producers appear on the list. However, there is still a significant majority of suppliers of own national origin. Monarchies may argue that the products from its own nation are more easily accessible, incidentally chosen by factors such as the royal families' individual taste, culture, history, tendencies in the country, etc. Recalling subsection 4.1.4, providing domestic products with the advantage of advertising ${ }^{245}$ subsidised by the state can affect the position of businesses from other Member States who seek to operate on the Danish or British market. It therefore indicates that the monarchies discriminate against suppliers from other Member States. In his book Det Koster et Kongerige, Danish journalist Jens Høvsgaard uncovers various examples of relations between the companies awarded royal warrants and the Danish monarchy's circle of friends. ${ }^{246}$

\subsection{National culture and tradition versus $E U$ integration and aims}

Royal warrants in both Denmark and UK are considered an old prestigious national tradition, going back before the establishment of the EU. The provisions of the TFEU have, together with the case law of the ECJ, led to a considerable limitation of autonomy and the removal or impact of numerous national traditions. ${ }^{247}$ However, as exemplified in Buy Irish, the ECJ has shown that it has a degree of tolerance for and understanding of the importance of tradition. Nevertheless, the internal market has priority ${ }^{248}$ and therefore several critics have argued that it appears that the EU does not care about national traditions or cultures. ${ }^{249}$ Nonetheless, in the EU Treaty it has been proclaimed that one of the goals

\footnotetext{
${ }^{243}$ Buy Irish (n 2066).

${ }^{244}$ See subsection 2.2.

245 The advertisement consists of the award of a royal warrant.

${ }^{246}$ Høvsgaard (n 20) 96-125.

247 Hojnik (n 20808) 310.

248 ibid.

249 Janja Hojnik draws attention to Case 407/85 Drei Glocken and others $v$ USL Centro-Sud and others [1988] ECR I-4233, where the ECJ dismissed traditional Italian pasta standards. Nonetheless, the AG stated that only Italians know the exact meaning of pasta terms, eg spaghetti, penne, linguine, bucatini, etc. Hojnik draws attention to a statement of a British MP in the 1980s, where the MP held that the EU had gone too far and were now threatening the British sausage by standardising it, which would influence the British way of life. Hojnik (n 20808) 311.
} 
of the EU is to deepen solidarity between peoples while respecting their distinct history, culture and traditions. Indeed, in its case law ${ }^{250}$ the ECJ has shown some sensitivity to national tradition. ${ }^{251}$ Janja Hojnik points to the fact that, although the ECJ tries to take national traditions into account, it is difficult to find a balance in cases where Member States try to justify ethnocentric campaigns. ${ }^{252}$ The author goes on to emphasise that in order for Member States to justify their ethnocentric campaigns, they will have to illustrate that a national tradition is the dominant and true goal of the campaign. ${ }^{253}$ In this respect, it is hard to justify cases like the Buy Irish or other 'campaigns' that promote domestic products with the aim of economic protectionism. In the case of royal warrants, the aim of the 'campaign' is to promote/favour own domestic products (since the majority of the suppliers are of own national origin). Even though royal warrants are an old tradition, it is difficult to justify them in accordance with Article 34 TFEU.

\subsection{A new approach}

In light of Buy Irish and the general prohibition of ethnocentric campaigns, the Commission has, in its recent Green Paper on promotion measures and information provision for agricultural products, ${ }^{254}$ adopted a new approach to local and regional food markets. Janja Hojink argued that the Commission's fresh approach could have significant consequences on the legitimacy of promoting national products ${ }^{255}$ and on the ruling set by Buy Irish. Furthermore, the promotion of agricultural products on the EU internal market is covered by specific EU law. ${ }^{256}$ In this way, the EU is trying to encourage consumers to buy EU agricultural products. ${ }^{257}$ However, as the ruling in Buy Irish established, the promotion of production based on national region is prohibited, except in cases of specific regions recognised by EU law. ${ }^{258}$

\footnotetext{
${ }^{250}$ Case C-36/02 Omega Spielhallen- und Autmoatenaufstellungs-GmbH $v$ Oberburgermeister der Bundesstadt Bonn [2004] ECR I-9609; Case C-210/06 Cartesio Oktató és Szolgáltató bt [2008] ECR I-9641; and Case C-208/09 Ilonka Sayn-Wittgenstein v Landeshauptmann von Wien [2010] ECR I-13693.

${ }^{251}$ Hojnik (n 20808) 311.

252 ibid.

253 ibid 312.

${ }^{254}$ Commission (EC) 'Promotion measures and information provision for agricultural products: A reinforced value-added European strategy for promoting the tastes of Europe' (Green Paper) COM(2011) 436 final, 14 July 2011.

255 Hojnik (n 20808) 292.

256 Council Regulation (EC) 3/2008 on information provision and promotion measures for agricultural products on the internal market and in third countries, [2008] OJ L3/1.

${ }^{257}$ According to Hojnik, the EU is initiating the purchase of EU agricultural products by co-financing promotional campaigns that highlight the quality, safety and nutritional value of EU farm products. Furthermore, it supports campaigns that draw attention to other intrinsic features and advantages of EU products. Hojnik (n 20808) 320.

258 Hojnik (n 20808) 321.
} 


\subsection{Final remarks}

As mentioned earlier, case law has shown that some ethnocentric campaigns are in accordance with the EU provision on the free movement of goods (Article 34 TFEU) under the condition that the campaign is solely organised by a private body or by the EU itself. However, campaigns sponsored by the state are in breach of Article $34 \mathrm{TFEU},{ }^{259}$ as can be derived from the examination in section 5 of this paper where the Danish and British monarchies can be seen as 'emanations of the state', which indicates that royal warrants are in breach of Article 34 TFEU. Furthermore, as AG Capotorti argues in his Opinion in the Buy Irish case, if one considers royal warrants as falling within the scope of state aid provisions, it follows that the UK and Denmark have failed to fulfil their obligations under EU law. Overall, it should be mentioned that it does not create a problem in itself that the royal families favour certain products or suppliers over others. Looking from the aspect that the royal members are individual persons, it may be considered that every individual person (royal or not) has different tastes and therefore it is their right to favour certain products over others. However, the essence of the problem is that the royal families, looking at the conclusions drawn in this paper, are to a certain degree state officials as heads of state, heavily funded by the state and regulated by public law (both in terms of their role, but also with regard to their legal responsibilities). Thus, their statements and acts, such as awarding royal warrants, are not acts undertaken by 'average citizens' (since other individuals would not have the same influence as public figures on sales) and thus royal warrants can be interpreted as being part of the state's official opinion and a campaign influenced by the state. It is therefore damaging for the internal market when monarchies announce that they prefer certain products over others by providing them with a special label, which can be linked to the state since it is an official mark with arms, seals, crowns, etc. It can be derived from the above examination that royal warrants give selected companies an advantageous position on the domestic and export markets by providing free advertising subsidised by the state. Royal warrants thus distort competition on the internal market both from the perspective of state aid and as a measure having effect equivalent to a barrier on the free movement of goods.

\section{Conclusion}

The predicate 'By appointment to the Royal Court' conveys prestige and favour deriving from the 'taste' of the members of the Danish and British monarchies. This paper has indicated that royal warrants provide a benefit for the companies thus awarded. Nonetheless, the paper has

259 ibid. 
not proven the effect of royal warrants on competition between companies operating in the single market due to the lack of relevant data and statistics on the topic, but it still indicates that, for some of the companies awarded, a royal warrant is important for their businesses. The lists of suppliers clearly indicate that monarchies favour products originating in their own country rather than in other EU Member States and thus discriminate against businesses there. All this suggests an ethnocentric campaign of national products. In general, royal warrants are not covered by the derogations from the prohibition on state aid. However, an individual assessment of each business awarded with a royal warrant is necessary.

Recalling the earlier assessment in subsection 4.3 covering derogations from the prohibition of state aid, royal warrants do not, in principle, fall within any of the categories listed in Article 107(2) and (3) TFEU, and therefore cannot be justified thereby. This indicates that royal warrants are most likely in breach of the EU provisions on state aid. However, whether the award of a royal warrant to a specific business can be justified by the exemption requires a case-by-case assessment.

This paper has examined the nature, tasks, finances and powers of the British and Danish monarchies under their countries' national law and it can be concluded that there is sufficient evidence to prove that both lie within the case law of the ECJ's definition of 'emanation of the state'. Especially in the UK, where the national courts have compiled a more thorough analysis on the aspect of emanation of the state in its case law, it appears that the monarchy is an emanation of the state. Literature indicates that both monarchies are attributable or imputable to the state and that public authorities are directly involved in some of the tasks and statements that derive from the monarchies. This paper has illustrated that, in respect of ethnocentric campaigns, there is a link between state aid and measures affecting the free movement of goods. AG Capotorti argued in his Opinion in Buy Irish that 'buy national' campaigns potentially distort competition by favouring certain companies over others. He also emphasised that the ethnocentric campaigns in Buy Irish ought rather to be covered by the provisions on state aid than be treated as a breach of Article 34 TFEU, as was held by the Commission and was also the approach of the ECJ. Although the institution of monarchy is seldom a topic of discussion, as it is almost 'sacred' for many and reflects old cultural and traditional national heritage, and despite its legal immunity and the judicial and political powers of the Danish and British monarchies, EU provisions on state aid and the internal market are still applicable. The relevant question here is whether it would be in accordance with EU law if, for example, the British Prime Minister provided quality labels saying that 10 Downing Street prefers certain British goods to products 
of other EU Member States. This would undoubtedly be a real threat to the internal market of the EU as it would send a clear signal to European consumers who may be highly influenced by the statements of their state official. In the case of this paper, consumers might be even more swayed by the statements of members of royal families.

Although the comparison may seem false, this paper clearly indicates that monarchies are an emanation of the state, ie they are on the same footing as any other undertaking within the concept of state, eg Southampton Health Authority in Marshall, private schools in NUT $v$ St Mary's Church of England School, British Gas Ltd in Foster v British Gas, the Goods Council of Ireland in Buy Irish and even universities as argued by AG Capotorti in his Opinion in Buy Irish.

Putting the question of monarchies as an emanation of the state into perspective, the research agenda could be extended to the monarchies' role in terms of the EU's provisions on public procurement and their purchase of specific goods or services or the receiving of gifts in relation to the aspect of 'a hidden advertisement' as a potential breach of the provisions of state aid. Furthermore, the Commission has recently increased its focus on state aid and in many areas, especially within broadcasting, aviation and public transport, has tightened the margin of what is defined as acceptable aid. It has also been given more efficient and effective tools to combat cases that seriously distort competition. However, the scope of this paper is limited and therefore the above questions remain unanswered. In conclusion, monarchies, blue blooded or not, are institutions under the same obligations of EU law as any other public body and should therefore comply with the applicable legislation on state aid and the internal market. 